\title{
PROSES POLITIK DALAM PEMBAHASAN RANPERDA KOTA PEKANBARU TENTANG RPJMD KOTA PEKANBARU \\ TAHUN 2017-2022
}

\begin{abstract}
The Regional Medium Term Development Plan (RPJMD) is one of the development planning documents that must be prepared by the regional government 6 months after the regional head is inaugurated. Vision The mission in the RPJMD is the vision and mission of the elected regional head offered to the community at the time of the campaign implementation in the implementation of the Regional Election Committee and adjustments that refer to the existing RPJPD. This means that the RPJMD is a political contract between the regional head and the community during his tenure (5 years).

The political process is also interpreted as a stage where there is interaction between the executive and the legislature in the legislative process, especially in relation to the discussion of the RPJMD which sets out the vision and mission of the regional head during his term of office. The legislative process is focused on the stages of discussion and agreement with the DPRD regarding the RPJMD and its relation to the performance of the future regional government.
\end{abstract}

Keywords: Development Planning, Political Process

* Rury Febrina, Isril

*Adalah Dosen Jurusan Ilmu Pemerintahan FISIP Universitas Riau

\section{PENDAHULUAN}

Perubahan sistem pemerintahan yang awalnya sangat sentralisasi dan didominasi oleh pemerintah pusat beralih menjadi terdesentralisasi sejak dimulainya era otonomi daerah. Pemerintah daerah diberikan wewenang yang lebih besar dan sumber keuangan baru (desentralisasi fiscal) yang lebih banyak untuk mendorong proses pembangunan didaerah (desentralisasi pembangunan). Kebijakan pembangunan daerah yang selama ini hanya pendukung dari kebijakan nasional, mulai mengalami perubahan sesuai dengan aspirasi yang berkembang di daerah.

Sejak dikeluarkannya Undang-Undang No. 25 Tahun 2004 tentang Sistem Perencanaan Pembangunan Nasional yang biasa disebut
Undang-Undang SPPN, kedudukan perencanaan pembangunan daerah di Indonesia menjadi semakin kuat ditandai dengan perubahan yang signifikan dalam proses penyusunan dokumen perencanaan pembangunan daerah. Perubahan yang cukup signifikan tersebut diantaranyal; Pertama, menyangkut dengan jenis dokumen perencanaan pembangunan daerah yang harus dibuat oleh masing-masing daerah sesuai dengan perkembangan demokratisasi dan otonomi dalam sistem pemerintahan daerah. Kedua, sesuai dengan perubahan jenis dokumen yang perlu dibuat maka teknik penyusunan rencana juga mengalami perubahan yang cukup mendasar. Ketiga, tahapan penyusunan rencana juga mengalami perubahan untuk dapat menerapkan sistem perencanaan partisipatif guna meningkatkan penyerapan aspirasi 
masyarakat dalam penyusunan rencana pembangunan. Dengan adanya Undang-Undang tersebut, maka penyusunan perencanaan menjadi suatu kewajiban yang harus dilakukan oleh setiap aparat pemerintah dalam melaksanakan kegiatan sehari-hari yang menekankan terhadap upaya mendorong atau mempercepat proses pembangunan daerah dalam rangka memenuhi tuntutan umum untuk dapat meningkatkan kesejahteraan masyarakat di daerah.

Perencanaan pembangunan daerah merupakan satu kesatuan dalam sistem perencanaan pembangunan nasional. Ruang lingkup perencanaan pembangunan daerah meliputi tahapan, tata cara penyusunan, pengendalian dan evaluasi pelaksanaan rencana pembangunan daerah, yang terdiri atas Rencana Pembangunan Jangka Panjang Daerah (RPJPD) yang berdurasi 20 Tahun, Rencana Pembangunan Jangka Menengah Daerah (RPJMD) yang berdurasi 5 Tahun, Rencana Strategis OPD berdurasi 5 Tahun, Rencana Kerja Pembangunan Daerah (RKPD) berdurasi 1 tahun, dan Rencana Kerja OPD berdurasi 1 tahun. Perencanaan pembangunan daerah juga mengintegrasikan rencana tata ruang dengan rencana pembangunan daerah. Perencanaan pembangunan daerah dilakukan pemerintah daerah bersama para pemangku kepentingan berdasarkan peran dan kewenangan masing-masing. Selain itu juga dilaksanakan berdasarkan kondisi dan potensi yang dimiliki daerah, sesuai dinamika perkembangan daerah dan nasional.

Rencana Pembangunan Jangka Menengah Daerah (RPJMD) merupakan salah satu dokumen perencanaan pembangunan yang wajib disusun oleh pemerintah daerah 6 bulan setelah kepala daerah dilantik. Visi Misi didalam RPJMD adalah visi misi kepala daerah terpilih yang ditawarkan kepada masyarakat pada saat pelaksanaan kampanye dalam pelaksanaan PILKADA dan dilakukan penyesuaian yang mengacu pada RPJPD yang telah ada. Hal ini bermakna bahwa RPJMD merupakan kontrak politik yang antara kepala daerah dengan masyarakat selama masa jabatannya (5 Tahun).
Berdasarkan Undang-Undang SPPN, dalam penyusunan RPJMD dilakukan dengan beberapa pendekatan teknokratis, pendekatan politis, pendekatan partisipatif, pendekatan top down dan buttom up. Pendekatan politis merupakan pendekatan yang ditawarkan oleh calon kepala daerah dan wakil kepala daerah terpilih pada saat kampanye lewat penerjemahan yang tepat dan sistematis atas visi, misi, dan program pembangunan serta pembahasan dengan DPRD dalam penetapan peraturan daerah tentang RPJMD.

Terdapat beberapa dinamika dan pemasalahan yang melingkup proses penyusunan hingga penetapan RPJMD diantaranya yaitu; Waktu 6 bulan penyusunan RPJMD jelas terbilang singkat sehingga sulit direalisasikan. Selain itu RPJMD yang ditetapkan dalam bentuk peraturan daerah menambah panjangnya waktu mengingat pembahasan yang melibatkan DPRD. Selain itu pelaksanaan pemilihan kepala daerah yang dilakukan melalui sistem pemilihan langsung berbeda-beda waktunya antara satu daerah dengan daerah lainnya, sehingga otomatis periode berlakunya RPJMD juga berbeda-beda antara satu daerah dengan daerah lainnya. Hal ini juga berdampak terhadap sulitnya memadukan RPJPD yang mempunyai jangka waktu yang sama disetiap daerah yaitu 2005-2025 dengan RPJMD yang tergantung pada masa jabatan kepala daerah. Akibatnya proses sinkronisasi dan konsistensi rencana pembangunan baik ditingkat nasional dan bersinergi dengan antar daerah sulit diwujudkan.

Dalam kerangka perencanaan pembangunan, Kota Pekanbaru telah menyusun dokumen RPJMD tahun 2017-2022 dan telah disahkannya bersama RPJMD Kota Pekanbaru tahun 2017-2022 merupakan dokumen yang strategis bagi pembangunan Kota Pekanbaru lima tahun ke depan melanjutkan RPJMD periode sebelumnya (2012-2017). Komisi Pemilihan Umum Kota Pekanbaru pada awal tahun 2017 telah menetapkan pasangan inkumben FirdausAyat Cahyadi sebagai Walikota Pekanbaru terpilih dalam pemilihan kepala daerah serentak 2017. 
Dokumen RPJMD ini merupakan dokumen yang menerjemahkan cita-cita Kepala Daerah terpilih yang dijelaskan dalam visi dan misi.

Berdasarkan penjelasan diatas, maka peneliti tertarik melihat secara mendalam proses penyusunan RPJMD dari mulai tahapan persiapan hingga mengkhususkan analisis pada tahapan politik yaitu pembahasan Ranperda RPJMD Kota Pekanbaru Tahun 2017-2022 bersama DPRD Kota Pekanbaru. Hal inilah yang mendasari penelitian yang akan dilakukan dengan tema Proses Politik dalam Pembahasan RANPERDA Kota Pekanbaru tentang RPJMD Kota Pekanbaru Tahun 2017-2022.

\section{RUMUSAN MASALAH}

Berdasarkan latar belakang yang telah dijelaskan di atas, dapat dirumuskan pertanyaan penelitian sebagai berikut: Bagaimana proses politik dalam pembahasan RANPERDA Kota Pekanbaru tentang RPJMD Kota Pekanbaru Tahun 2017-2022?

\section{KERANGKA TEORITIS}

\section{Kebijakan Publik}

Carl J Federick sebagaimana dikutip Leo Agustino $^{1}$ mendefinisikan kebijakan sebagai serangkaian tindakan/kegiatan yang diusulkan seseorang, kelompok atau pemerintah dalam suatu lingkungan tertentu dimana terdapat hambatanhambatan (kesulitan-kesulitan) dan kesempatankesempatan terhadap pelaksanaan usulan kebijaksanaan tersebut dalam rangka mencapai tujuan tertentu. Pendapat ini juga menunjukan bahwa ide kebijakan melibatkan perilaku yang memiliki maksud dan tujuan merupakan bagian yang penting dari definisi kebijakan, karena bagaimanapun kebijakan harus menunjukan apa yang sesungguhnya dikerjakan daripada apa yang diusulkan dalam beberapa kegiatan pada suatu masalah.
Solichin Abdul Wahab mengemukakan bahwa istilah kebijakan sendiri masih terjadi silang pendapat dan merupakan ajang perdebatan para ahli. Maka untuk memahami istilah kebijakan, Solichin Abdul Wahab memberikan beberapa pedoman sebagai berikut ${ }^{2}$ :

a. Kebijakan harus dibedakan dari keputusan

b. Kebijakan sebenarnya tidak serta merta dapat dibedakan dari administrasi

c. Kebijakan mencakup perilaku dan harapanharapan

d. Kebijakan mencakup ketiadaan tindakan ataupun adanya tindakan

e. Kebijakan biasanya mempunyai hasil akhir yang akan dicapai

f. Setiap kebijakan memiliki tujuan atau sasaran tertentu baik eksplisit maupun implisit

g. Kebijakan muncul dari suatu proses yang berlangsung sepanjang waktu

h. Kebijakan meliputi hubungan-hubungan yang bersifat antar organisasi dan yang bersifat intra organisasi.

i. Kebijakan publik meski tidak ekslusif menyangkut peran kunci lembaga-lembaga pemerintah

j. Kebijakan itu dirumuskan atau didefinisikan secara subyektif.

Richard Rose sebagaimana dikutip Budi Winarno ${ }^{3}$ menyarankan bahwa kebijakan hendaknya dipahami sebagai serangkaian kegiatan yang sedikit banyak berhubungan beserta konsekuensi-konsekuensi bagi mereka yang bersangkutan daripada sebagai keputusan yang berdiri sendiri. Pendapat kedua ahli tersebut setidaknya dapat menjelaskan bahwa mempertukarkan istilah kebijakan dengan keputusan adalah keliru, karena pada dasarnya kebijakan dipahami sebagai arah atau pola kegiatan dan bukan sekadar suatu keputusan untuk melakukan sesuatu.

Berdasarkan pendapat berbagai ahli tersebut di atas maka dapat disimpulkan bahwa kebijakan adalah tindakan-tindakan atau kegiatan yang sengaja dilakukan atau tidak dilakukan oleh 
seseorang, suatu kelompok atau pemerintah yang di dalamnya terdapat unsur keputusan berupa upaya pemilihan diantara berbagai alternatif yang ada guna mencapai maksud dan tujuan tertentu.

Selanjutnya akan dibahas kebijakan publik. Lingkup dari studi kebijakan publik sangat luas karena mencakup berbagai bidang dan sektor seperti ekonomi, politik, sosial, budaya, hukum, dan sebagainya. Disamping itu dilihat dari hirarkirnya kebijakan publik dapat bersifat nasional, regional maupun lokal seperti undangundang, peraturan pemerintah, peraturan presiden, peraturan menteri, peraturan pemerintah daerah/ provinsi, keputusan gubernur, peraturan daerah kabupaten/kota, dan keputusan bupati/walikota. Secara terminologi pengertian kebijakan publik (public policy) itu ternyata banyak sekali, tergantung dari sudut mana kita mengartikannya.

Easton memberikan definisi kebijakan publik sebagai the authoritative allocation of values for the whole society atau sebagai pengalokasian nilai nilai secara paksa kepada seluruh anggota masyarakat. Laswell dan Kaplan juga mengartikan kebijakan publik sebagai $a$ projected program of goal, value, and practice atau sesuatu program pencapaian tujuan, nilai-nilai dalam praktek-praktek yang terarah.

Proses pembuatan kebijakan publik merupakan proses yang kompleks karena melibatkan banyak proses maupun variabel yang harus dikaji. Oleh karena itu beberapa ahli politik yang menaruh minat untuk mengkaji kebijakan publik membagi proses-proses penyusunan kebijakan publik kedalam beberapa tahap. Tujuan pembagian seperti ini adalah untuk memudahkan kita dalam mengkaji kebijakan publik. Namun demikian, beberapa ahli mungkin membagi tahaptahap ini dengan urutan yang berbeda. Tahap-tahap kebijakan publik menurut William Dunn sebagaimana dikutip Budi Winarno adalah sebagai berikut ${ }^{4}$ :

\section{a. Tahap Penyusunan Agenda}

Para pejabat yang dipilih dan diangkat menempatkan masalah pada agenda publik.
Sebelumnya masalah ini berkompetisi terlebih dahulu untuk dapat masuk dalam agenda kebijakan. Pada akhirnya, beberapa masalah masuk ke agenda kebijakan para perumus kabijakan. Pada tahap ini mungkin suatu masalah tidak disentuh sama sekali, sementara masalah yang lain ditetapkan menjadi fokus pembahasan, atau ada pula masalah karena alasanalasan tertentu ditunda untuk waktu yang lama.

\section{b. Tahap Formulasi Kebijakan}

Masalah yang telah masuk ke agenda kebijakan kemudian dibahas oleh para pembuat kebijakan. Masalah-masalah tadi didefinisikan untuk kemudian dicari pemecahan masalah terbaik. Pemecahan masalah tersebut berasal dari berbagai alternatif atau pilihan kebijakan (policy alternatives/policy options) yang ada. Dalam perumusan kebijakan masing-masing alternatif bersaing untuk dapat dipilih sebagai kebijakan yang diambil untuk memecahkan masalah. Dalam tahap ini masing-masing actor akan bersaing dan berusaha untuk mengusulkan pemecahan masalah terbaik.

c. Tahap Adopsi Kebijakan

Dari sekian banyak alternatif kebijakan yang ditawarkan oleh para perumus kebijakan, pada akhirnya salah satu dari alternatif kebijakan tersebut diadopsi dengan dukungan dari mayoritas legislatif, konsensus antara direktur lembaga atau putusan peradilan.

\section{d. Tahap Implementasi Kebijakan}

Suatu program kebijakan hanya akan menjadi catatan-catatan elit jika program tersebut tidak diimplementasikan, yakni dilaksanakan oleh badan-badan administrasi maupun agen-agen pemerintah di tingkat bawah. Kebijakan yang telah diambil dilaksanakan oleh unit-unit administrasikan yang memobilisasikan sumber daya finansial dan manusia. Pada tahap implementasi ini berbagai kepentingan akan saling bersaing. Beberapa implementasi kebijakan mendapat dukungan para pelaksana (implementors), namun beberapa yang lain munkin akan ditentang oleh para pelaksana. 


\section{e. Tahap Evaluasi Kebijakan}

Dalam tahap ini kebijakan yang telah dijalankan akan dinilai atau dievaluasi, unuk melihat sejauh mana kebijakan yang dibuat untuk meraih dampak yang diinginkan, yaitu memecahkan masalah yang dihadapi masyarakat. Oleh karena itu ditentukan ukuran-ukuran atau kriteria-kriteria yamh menjadi dasar untuk menilai apakah kebijakan publik yang telah dilaksanakan sudah mencapai dampak atau tujuan yang diinginkan atau belum.

\section{Perencanaan Pembangunan}

Menurut Arthur W.Lewis yang dikutip oleh Sjafrizal, perencanaan pembangunan sebagai suatu kumpulan kebijaksanaan dan program pembangunan untuk merangsang masyarakat dan swasta untuk menggunakan sumber daya yang tersedia secara lebih produktif 5 . Selain itu menurut M.L. Jhingan, Perencanaan pembangunan pada dasarnya adalah merupakan pengendalian dan pengaturan perekonomian dengan sengaja oleh suatu penguasa (pemerintah) pusat untuk mencapai suatu sasaran dan tujuan di dalam jangka waktu tertentu pula ${ }^{6}$. Hal ini sejalan dengan apa yang dikatakan oleh Michael Todaro didalam Sjafrizal yang mendefinisikan bahwa perencanaan ekonomi dapat digambarkan sebagai berikut; "suatu upaya pemerintah secara sengaja untuk melakukan koordinasi pengambilan keputusan ekonomi dalam jangka panjang untuk mempengaruhi secara langsung maupun tidak langsung tingkat pertumbuhan dari beberapa variable utama perekonomian nasional"”.

Perencanaan pembangunan mempunyai berbagai jenis, tergantung dari sifatnya masingmasing. Mengikuti Lincolin Arsyad, menurut jangka waktunya perencanaan pembangunan dapat dibagi menjadi perencanaan jangka panjang, perencanaan jangka menengah dan perencanaan jangka pendek. Selanjutnya berdasarkan sifatnya perencanaan pembangunan komando (central planning), dan perencanaan dengan rangsangan (planning by insentive). Berdasarkan alokasi sumber daya, perencanaan pembangunan dibagi atas dua jenis, yaitu; perencanaan keuangan dan perencanaan fisik. Berdasarkan tingkat keluwesan, perencanaan pembangunan dikelompokkan atas perencanaan indikatif dan perencanaan imperative. Sedangkan berdasarkan sistem ekonomi, perencanaan pembangunan dikelompoknya atas tiga yaitu; perencanaan pembangunan kapitalisme, perencanaan pembangunan dalam sistem komunis, dan perencanaan pembangunan dalam sistem campuran. Trakhir perencanaan pembangunan berdasarkan cara pelaksanaannya dibagi atas dua yaitu perencanaan sentralistik dan perencanaan desentralistik ${ }^{8}$.

Perencanaan pembangunan mempunyai beberapa jenis, menurut Lincolin Arsyad yang dikutip oleh Sjafrizal (2014: 30) terdapat tiga jenis klasifikasi perencanaan pembangunan berdasarkan jangka waktunya yaitu:

\section{a. Perencanaan Jangka Panjang}

Perencanaan jangka panjang biasanya mencakup jangka waktu 10-25 tahun. Rencana jangka panjang (Long-term Planing) biasanya disebut juga sebagai perencanaan perspektif (Perspektive Planing) yang berisikan arah pembangunan secara umum. Dengan kata lain, perencanaan jangka panjang berisikan pandangan jauh ke depan tentang kerangka pembangunan yang disusun sesuai aspirasi masyarakat secara umum.

\section{b. Perencanaan Jangka Menengah}

Perencanaan jangka menengah (Mediumterm Planing) biasanya mencakup waktu 4-5 tahun, tergantung dari masa jabatan presiden atau kepala daerah. Perencanaan jangka menengah pada dasarnya merupakan jabaran dari perencanaan jangka panjang sehingga bersifat lebih operational dan disusun berdasarkan visi dan misi kepala daerah terpilih.

\section{c. Perencanaan Jangka Pendek}

Perencanaan jangka pendek biasanya mencakup waktu hanya 1 tahun sehingga sering kali dinamakan rencana tahunan (Annual Planing) 
Rencana ini pada dasarnya merupakan jabaran dari rencana jangka menengah. Disamping itu, rencana tahunan ini bersifat lebih operational karena didalamnya terdapat program dan kegiatan, lengkap dengan pendanaanya.

Perencanaan pembangunan daerah merupakan kegiatan yang tidak mudah karena akan berhadapan dengan berbagai permasalahan yang sangat kompleks dan komprehensif (meliputi berbagai aspek social kemasyarakatan) dari suatu keadaan yang ada diwilayah terkait. Kompleksitas permasalahan tersebut sudah menjadi konsekuensi logis yang harus dihadapi dan tidak mungkin dihindari. Sehubungan dengan hal tersebut, dalam perencanaan pembangunan daerah ada beberapa aspek yang perlu mendapatkan perhatian agar perencanaan pembangunan dapat diimplementasikan dilapangan, adapun aspekaspek tersebut yaitu';

1. Aspek lingkungan. Hal ini penting karena lingkungan memiliki dampak yang sangat besar terhadap berhasil tidaknya program pembangunan. Berdasarkan ruang lingkupnya, aspek lingkungan dibagi menjadi dua yaitu lingkungan internal dan eksternal. Aspek lingkungan ini dapat meliputi bidang social, budaya, politik dan lainnya.

2. Aspek potensi masalah. Potensi dan masalah merupakan fakta yang ada dilapangan dan sangat berpengaruhi terhadap proses pembangunan bahkan hal tersebut dapat menjadi pedoman dasar analisis program pembangunan.

3. Aspek institusi pelaksana. Institusi pelaksana adalah organisasi pemerintahyang bertanggung jawab melakukan perencanaan pembangunan daerah. Karena pada dasarnya pembangunan merupakan tugas pemerintah dalam rangka memenuhi kewajiban-kewajiban kepada masyarakat. Institusi perencana berperan sebagai pelaksana fungsi manajemen didalam bidang perencanaan dan pembangunan.

4. Aspek ruang dan waktu. Pembatasan ruang dan waktu menggambarkan kebutuhan timing yang tepat tentang kapan perencanaan pembangunan daerah itu disusun, kapan dimulai, dan berapa lama jangka waktu pemberlakuannya, serta kapan dilakukan evaluasi atau perencanaan ulang.

5. Aspek legalitas kebijakan. Aspek ini penting ketika hasil perencanaan pembangunan daerah dipandang sebagai suatu keputusan dari suatu kebijakan yang bersifat mengikat dan harus dilaksanakan. Pelanggaran terhadap hasil perencanaan dapat dipandang sebagai tindakan penyelewengan yang dapat berimplikasi hukum terhadap para pelanggarnya.

Hubungan antara politik dan perencanaan pembangunan dikemukan oleh Bintaro diantaranya yaitu ${ }^{10}$

1. Aspek politik yang mempunyai pengaruh timbal balik dengan administrasi pembangunan adalah filsafah hidup bangsa atau filsafat politik kemasyarakatn dari suatu Negara tertentu. Hal ini berhubungan dengan interdependensi antara sistem politik yang dianut dengan administrasi pembangunan.

2. Komitmen dari elite kekuasaan/elite pemerintah terhadap proses pembangunan dan ketersediaan menerima pendekatan yang sungguh-sungguh terhadap usaha yang saling terkait antara berbagai segi kehidupan masyarakat.

3. Masalah yang berhubungan dengan kestabilan politik

4. Perkembangan bidang politik kearah pemberian iklim politik yang menunjang usaha pembangunan.

\section{METODE PENELITIAN}

Penelitianini merupakan penelitian kualitatif yang menurut Denzin dan Lincoln dalam Lexy J. Moleong (2008: 5) yakni penelitian yang menggunakan latar alamiah, dengan maksud menafsirkan fenomena yang terjadi dan dilakukan dengan jalan melibatkan metode yang ada. Tipe penelitian yang digunakan adalah tipe deskriptif yaitu suatu metode yang digunakan untuk menemukan pengetahuan yang seluas-luasnya terhadap objek penelitian pasa suatu saat tertentu.. 
Teknikmenentukaninforman yakni dengan teknik purposif. Artinya dalam konteks penelitian ini informan dipilih berdasarkan atas kewenangan yang dimilikinya dan keterlibatan dalam permasalahan penelitian yang dikaji. Teknik pengumpulan data yang dipergunakan dalam penelitian ini dengan menggunakan metode sebagai berikut:

1. Wawancara mendalam, teknik ini bertujuan untuk mendapatkan informasi yang detail mengenai permasalahan penelitian.

2. Penelusuran dokumen, metode ini digunakan untuk melengkapi data dari pihak pertama yakni dari informan penelitian sehingga diperoleh data dan fakta otentik dalam penelitian ini.

Analisis data dalam penelitian kualitatif menurut Miles dan Huberman diklasifikasikan menjadi 3 (tiga) teknik yakni ${ }^{11}$; pertama reduksi data yakni bentuk analisis yang menajamkan, menggolongkan, mengarahkan, membuang yang tidak perlu dan mengorganisasi data sedemikan rupa sehingga kesimpulan akhir dapat diambil. Kedua, penyajian data yakni kegiatan mengumpulkan, menyusun informasi untuk memberi kemungkinan dalam menarik kesimpulan. Ketiga, penarikan kesimpulan yang merupakan hasil analisis dari data yang diperoleh dan dianalisis menggunakan teori yang relevan.

\section{HASIL DAN PEMBAHASAN}

Rencana Pembangunan Jangka Menengah Daerah (RPJMD) merupakan salah satu dokumen perencanaan pembangunan yang wajib disusun oleh pemerintah daerah 6 bulan setelah kepala daerah dilantik. Visi Misi didalam RPJMD adalah visi misi kepala daerah terpilih yang ditawarkan kepada masyarakat pada saat pelaksanaan kampanye dalam pelaksanaan PILKADA dan dilakukan penyesuaian yang mengacu pada RPJPD yang telah ada. Hal ini bermakna bahwa RPJMD merupakan kontrak politik yang antara kepala daerah dengan masyarakat selama masa jabatannya (5 Tahun).
Penetapan RPJMD juga diamanatkan didalam Pasal 264 ayat (1) dan (4) undang-undang nomor 23 tahun 2014 tentang pemerintahan daerah, yang menyatakan bahwa :

(1) RPJPD dan RPJMD sebagaimana dimaksud dalam pasal 263 ayat (1) huruf a dan huruf b ditetapkan dengan peraturan daerah.

(2) Peraturan daerah tentang RPJMD ditetapkan paling lama 6 (enam) bulan setelah kepala daerah terpilih dilantik.

Penetapan RPJMD juga memiliki konsekwensi dimana apabila penyelenggara pemerintahan daerah tidak menetapkan peraturan daerah tentang RPJPD dan RPJMD sebagaimana dimaksud dalam pasal 264 ayat (3) dan ayat (4), anggota DPRD dan Kepala Daerah dikenai sanksi administratif berupa tidak dibayarkan hak-hak keuangan yang diatur dalam ketentuan peraturan perundang-undangan selama 3 (tiga) bulan.

RPJMD Kota Pekanbaru Tahun 2017-2022 merupakan tahap ketiga dari pelaksanaan Rencana Pembangunan Jangka Panjang Daerah (RPJPD) Kota Pekanbaru Tahun 2005-2025. RPJMD ini selanjutnya menjadi pedoman bagi seluruh Perangkat Daerah (PD) dalam menyusun Rencana Strategis (Renstra) PD. Untuk pelaksanaan lebih lanjut, RPJMD ini akan dijabarkan ke dalam Rencana Kerja Pembangunan Daerah (RKPD) yang akan menjadi pedoman bagi penyusunan Rencana Anggaran Pendapatan dan Belanja Daerah (RAPBD) pada tahapan tahunannya.

Dalam penelitian ini juga ditemukan persoalan transisi pergantian peraturan perundangundangan terkait tata cara penyusunan RPJMD dimana Peraturan Menteri Dalam Negeri (Permendagri) Nomor 54 Tahun 2010 tentang Pelaksanaan Peraturan Pemerintah Nomor 8 Tahun 2008 tentang Tahapan, Tata Cara Penyusunan, Pengendalian, dan Evaluasi Pelaksanaan Rencana Pembangunan Daerah dicabut dan digantikan dengan Peraturan Menteri Dalam Negeri Nomor 86 Tahun 2017 tentang Tata Cara Perencanaan, Pengendalian dan Evaluasi Pembangunan Daerah, Tata Cara Evaluasi Rancangan Peraturan Daerah Tentang Rencana Pembangunan Jangka Panjang 
Daerah dan Rencana Pembangunan Jangka Menengah Daerah, Serta Tata Cara Perubahan Rencana Pembangunan Jangka Panjang Daerah, Rencana Pembangunan Jangka Menengah Daerah, dan Rencana Kerja Pemerintah Daerah. Pergantian ini mempengaruhi proses penyusunan RPJMD yang telah dimulai penyusunannya di Tahun 2016.

Penelitian ini memfokuskan mengelaborasi interaksi politik pemerintah Kota Pekanbaru dengan DPRD Kota Pekanbaru pada tahapan pembahasan dan penetapan Peraturan Daerah tentang RPJMD Kota Pekanbaru Tahun 20172022. Hal ini menarik dikasi mengingat penyusunan RPJMD dilakukan dengan beberapa pendekatan diantaranya yaitu pendekatan politis yang merupakan pendekatan yang ditawarkan oleh calon kepala daerah dan wakil kepala daerah terpilih pada saat kampanye lewat penerjemahan yang tepat dan sistematis atas visi, misi, dan program pembangunan serta pembahasan dengan DPRD dalam penetapan peraturan daerah tentang RPJMD Kota Pekanbaru 2017-2022.

RPJMD ditetapkan dengan peraturan daerah. Berdasarkan Undang-Undang No 12 Tahun 2011 tentang Pembentukan Peraturan Perundang-Undangan dan Peraturan Dewan Perwakilan Rakyat Daerah (DPRD) Kota Pekanbaru No 01 Tahun 2017 tentang Perubahan Pertama Atas Peraturan Dewan Perwakilan Rakyat Daerah Kota Pekanbaru Nomor 08/KPTS/ DPRD/2014 tentang tata tertib Dewan Perwakilan Rakyat Daerah (DPRD) Kota Pekanbaru. Pada Bab X memuat tentang tata cara pembentukan peraturan daerah. Dimana pada pasal 102-110 diatur tahapan yang dilalui dalam penyusunan peraturan daerah khususnya tertuang dipasal 106 yaitu;

\section{Pasal 106}

(1) Rancangan peraturan daerah yang berasal dari DPRD atau Kepala daerah dibahas oleh DPRD dan Kepala Daerah untuk mendapat persetujuan bersama.

(2) Pembahasan rancangan peraturan daerah sebagaiman dimaksud pada ayat (1), dilakukan dengan 2 (dua) tingkat pembicaraan yaitu pembicaraan tingkat I dan pembicaraan tingkat II.

(3) Pembicaraan tingkat I sebagaimana dimaksud pada ayat (2) meliputi;

a. Dalam hal rancangan peraturan daerah berasal dari Kepala Daerah dilakukan dengan kegiatan sebagai berikut:

1. Penjelasan Kepala Daerah dalam rapat paripurna mengenai rancangan peraturan daerah.

2. Pandangan umum fraksi terhadap rancangan peraturan daerah dan

3. Tanggapan dan/atau jawaban Kepala Daerah terhadap pandangan umum fraksi sekaligus pembentukan Pansus.

c. Pembahasan dalam rapat komisi, gabungan komisi, atau panitia khusus yang dilakukan bersama dengan Kepala Daerah atau pejabat yang ditunjuk untuk mewakili.

(4) Pembicaraan tingkat II sebagaimana dimaksu pada ayat (2) meliputi;

a. Pengambilan keputusan bersama dalam rapat paripurna yang didahului dengan:

1. Penyampaian laporan pimpinan komisi/ pimpinan, gabungan komisi/pimpinan panitia khusus yang berisi proses pembahasan, pendapat fraksi dan hasil pembicaraan sebagaimana dimaksud pada ayat(3) huruf c; dan

2. Permintaan persetujuan dari anggota secara lisan oleh pimpinan rapat paripurna.

b. Pendapat akhir kepala daerah.

Proses politik juga dimaknai sebagai tahapan dimana terjadi interaksi eksekutif dengan legislatif dalam proses legislasi khususnya terkait pembahasan RPJMD yang menuangkan visi misi kepala daerah selama masa jabatannya. Proses legislasi dikhusukan pada tahapan pembahasan dan persetujuan bersama DPRD terkait RPJMD dan kaitannya dengan kinerja pemerintah daerah kedepannya. Pembahasan juga berkorelasi terhadap pelaksanaan dari fungsi DPRD baik pengganggaran dan pengawasan yang dilakukan selama masa jabatan kepala daerah. 
Selain itu RPJMD sebagai bahan evaluasi keberhasilan Walikota yang pada proses pelaksanaannya dapat mencapai target atau tidak disebabkan oleh banyak faktor baik finasial maupun sumber daya lainnya.

Berdasarkah ketentuan didalam Tatib, dapat dijabarkan bahwa tindak lanjut pembahasan rancangan peraturan daerah (Ranperda) yang berasal dari DPRD atau Kepala Daerah dilakukan melalui 2 tingkatan pembicaraan, yaitu pembicaraan tingkat 1 dilakukan dalam rapat komisi, rapat gabungan komisi, rapat badan pembentukan peraturan daerah, rapat badan anggaran atau rapat panitia khusus. Kemudian dilanjutkan dengan pembicaraan tingkat 2 dilakukan dalam rapat paripurna.

Adapun tahapan pembicaraan tingkat 1 dan tingkat 2 pembahasan Ranperda Kota Pekanbaru tentang RPJMD Kota Pekanbaru tahun 2017-2022 dilaksanakan secara meraton dari Oktober-November 2017 dengan rincian dapat dilihat pada tabel 1 berikut;

\section{Tabel 1. Tahapan Pembahasan Ranperda Kota Pekanbaru tentang RPJMD Kota Pekanbaru Tahun 2017-2022}

\begin{tabular}{|c|c|c|c|}
\hline No. & Tanggal & Kegiatan & Agenda/Materi \\
\hline 1. & 09 Oktober 2017 & $\begin{array}{l}\text { Rapat Paripurna Ke } 5 \\
\text { Masa Sidang III } \\
\text { Tahun } 2017\end{array}$ & $\begin{array}{l}\text { Penyampaian/Penjelasan oleh Walikota } \\
\text { Pekanbaru tentang Ranperda RPJMD Kota } \\
\text { Pekanbaru tahun 2017-2022 }\end{array}$ \\
\hline 2. & 18 Oktober 2017 & $\begin{array}{l}\text { Rapat Paripurna Ke } 6 \\
\text { Masa Sidang III } \\
\text { Tahun } 2017\end{array}$ & $\begin{array}{l}\text { Penyampaian pandangan umum fraksi } \\
\text { DPRD Kota Pekanbaru tentang Ranperda } \\
\text { RPJMD Kota Pekanbaru tahun 2017-2022. }\end{array}$ \\
\hline 3. & 19 Oktober 2017 & $\begin{array}{l}\text { Rapat Paripurna Ke } \\
17 \text { Masa Sidang III } \\
\text { Tahun } 2017\end{array}$ & $\begin{array}{l}\text { Jawaban pemerintah terhadap padangan } \\
\text { umum fraksi DPRD Kota Pekanbaru } \\
\text { tentang Ranperda RPJMD Kota Pekanbaru } \\
\text { tahun 2017-2022. }\end{array}$ \\
\hline 4. & 24 Oktober 2017 & $\begin{array}{l}\text { Rapat Kerja Panitia } \\
\text { Khusus bersama tim } \\
\text { ahli dan pemerintah } \\
\text { Kota Pekanbaru }\end{array}$ & $\begin{array}{l}\text { Ekspose Kepala Bappeda Pekanbaru } \\
\text { mengenai RPJMD } 2017 \quad-2022 \text { (do kumen } \\
\text { awal). }\end{array}$ \\
\hline 5. & 1 November 2017 & $\begin{array}{l}\text { Rapat Kerja Panitia } \\
\text { Khusus bersama tim } \\
\text { ahli dan pemerintah } \\
\text { Kota Pekanbaru }\end{array}$ & $\begin{array}{l}\text { Ekspose Kepala Bappeda Pekanbaru } \\
\text { mengenai RPJMD 2017 -2022 setelah } \\
\text { diperbaiki berdasarkan konsultasi } \\
\text { rancangan akhir RPJMD Kota Pekanbaru } \\
\text { 2017-2022 ke Pemerintah Provinsi Riau. }\end{array}$ \\
\hline 6. & $\begin{array}{l}19 \text { November } \\
2017\end{array}$ & $\begin{array}{l}\text { Rapat Kerja Panitia } \\
\text { Khusus bersama tim } \\
\text { ahli dan pemerintah } \\
\text { Kota Pekanbaru }\end{array}$ & $\begin{array}{l}\text { Finalisasi RPJMD Kota Pekanbaru } 2017 \text { - } \\
2022 .\end{array}$ \\
\hline 7. & $\begin{array}{l}20 \text { November } \\
2017\end{array}$ & $\begin{array}{l}\text { Rapat Paripurna Ke } \\
11 \text { Masa Sidang III } \\
\text { Tahun } 2017\end{array}$ & $\begin{array}{l}\text { Laporan panitia khusus DPRD Kota } \\
\text { Pekanbaru terhadap Ranperda Kota } \\
\text { Pekanbaru tentang RPJMD Kota } \\
\text { Pekanbaru 2017-2022 dan pendapat akhir } \\
\text { kepala d aerah terhadap laporan panitia } \\
\text { khusus DPRD Kota Pekanbaru tentang } \\
\text { Ranperda RPJMD Kota Pekanbaru tahun } \\
\text { 2017-2022. }\end{array}$ \\
\hline
\end{tabular}

Pada tahapan awal terjadi keterlambatan dalam proses politik pembahasan draft RPJMD hal ini disebabkan belum disahkannya dokumen RTRW yang juga menjadi pedoman dasar dalam penyusunan RPJMD. Selain itu terjadi keterlambatan dimulainya pembahasan akibat tidak adanya anggaran untuk pembahasan Perda RPJMD sehingga menunggu APBD perubahan disahkan. Namun hal berbeda dari perspektif DPRD terkait dinamika politik RPJMD juga tidak terlalu menguat atau menjadi komoditas politik DPRD, hal ini disebabkan oleh kasipnya waktu pembahasan yang hanya tinggal 1 bulan lagi dari tenggat waktu pengesahan RPJMD yang telah ditetapkan didalam Peraturan PerundangUndangan. Pemerintah Daerah disini dinilai terlambat menyampaikan usulan pembahasan Ranperda RPJMD ke DPRD.

\section{A. Penyampaian oleh Walikota Pekanbaru tentang Ranperda RPJMD Kota Pekanbaru tahun 2017-2022 dalam Rapat Paripurna}

Rapat paripurna yang merupakan tahapan awal pembahasan RPJMD Kota Pekanbaru Tahun 2017-2022 ini dilakukan menindak lanjuti surat sekretariat daerah Kota Pekanbaru No. 180/HK/ IX/2017/178 perihal penyampaian usulan Penyusunan Program Peraturan Daerah (Propemperda) Pemerintah Kota Pekanbaru Tahun 2017 dan surat No. 180/HK/IX/2017/179 perihal penjadwalan paripurna dimana terdapat 13 Ranperda Kota Pekanbaru yang diusulkan oleh Pemerintah Kota Pekanbaru salah satunya yaitu Ranperda RPJMD Kota Pekanbaru Tahun 20172022. Pada tahapan awal ini Pemerintah Kota Pekanbaru menyampaikan tentang Ranperda RPJMD Kota Pekanbaru Tahun 2017-2022 yang dilaksanakan pada tanggal 09 Oktober 2017. Pemerintah Walikota Pekanbaru yang diwakilkan oleh Sekretaris Daerah menyampaikan beberapa poin pokok didalam penyampaian awal ini diantaranya ${ }^{12}$;

1. Kedudukan RPJMD yang sangat penting dan strategis untuk menjaga kesinambungan pembangunan daerah. 
Ketiadaan dokumen RPJMD akan menimbulkan kekosongan perencanaan yang berimplikasi pada penyusunan Rencana Kerja Pemerintah Dearah (RKPD) tahunan dan penyusunan Anggaran Pendapatan Belanja Daerah (APBD) selama kurun waktu 5 Tahun

2. Tahapan ini jika mengikuti jadwal yang telah ditetapkan masih dalam kondisi yang on the track dimana masih ada waktu sekitar 1 bulan setengah untuk membahas Ranperda sehingga bisa ditetapkan sebagai perda.

Walikota Pekanbaru terpilih Bapak Dr. H. Firdaus ST, MT dan Wakil Walikota Bapak Ayat Cahyadi dilantik pada tanggal 22 Mei 2017 dan Peraturan daerah tentang RPJMD ditetapkan paling lama 6 (enam) bulan setelah kepala daerah terpilih dilantik. Limit terakhir penetapan jatuh pada bulan November 2017. Tidak terjadi keterlambatan dalam pengusulan yang dilakukan pada satu bulan sebelum limit trakhir penetapan Perda RPJMD. Setelah Rancangan Peraturan Daerah Rencana Pembangunan Jangka Menengah Daerah (RPJMD) Tahun 2017-2022 disampaikan oleh Walikota Kota Pekanbaru terpilih kepada Dewan Perwakilan Rakyat Daerah Kota Pekanbaru dalam Sidang Paripurna Dewan Perwakilan Daerah Kota Pekanbaru, maka dimulai proses politik untuk membahas Ranperda RPJMD menjadi Perda RPJMD tahun 2017-2022. Secara umum proses politik dalam pembahasan RPJMD Kota Pekanbaru tahun 2017-2022 tidak mengalami dinamika yang cukup kuat.

\section{B. Penyampaian Pandangan Umum Fraksi DPRD Kota Pekanbaru dalam Rapat Paripurna tentang Ranperda RPJMD Kota Pekanbaru tahun 2017-2022.}

Proses dan tahap awal yang dilakukan di DPRD Kota Pekanbaru sesuai dengan Tata Tertib DPRD Kota Pekanbaru yaitu melakukan pandangan umum dari setiap Fraksi yang ada di
DPRD Kota Pekanbaru terhadap Rancangan Peraturan Daerah tentang RPJMD Kota Pekanbaru tahun 2017-2022. Pentingnya pandangan umum disampaikan oleh Fraksi yang ada di DPRD karena Fraksi merupakan perpanjangan tangan dari Partai Politik sebagai wujud dari menyalurkan kepentingan dan aspirasi masyarakat, walaupun Fraksi bukan alat kelengkapan DPRD Kota Pekanbaru. Secara yuridis formal pentingnya aspirasi dan keterlibatan masyarakat dalam pembahasan produk hukum daerah dapat dilihat dalam Undang-Undang Nomor 12 Tahun 2011 tentang Pembentukan Peraturan Perundang-undangan tepatnya pasal 96 jo Peraturan Menteri Dalam Negeri Nomor 80 Tahun 2015 Tentang Produk Hukum Daerah tepatnya:

- Pasal 96(1) Masyarakat berhak memberikan masukan secara lisan dan/tertulis dalam pembentukan Peraturan PerundangUndangan.

- Pasal 196(1) Masyarakat berhak memberikan masukan secara lisan dan/atau tertulis dalam pembentukan perda, perkada, PB KDH dan/ atau peraturan DPRD

Untuk diketahui bahwa pandangan umum yang disampaikan oleh Fraksi-Fraksi di DPRD Kota Pekanbaru dalam sidang paripurna DPRD Kota Pekanbaru yaitu untuk merespon Visi, Misi Walikota terpilih yang berkaiatan dengan kebijakan Pemerintah Kota Pekanbaru untuk menjadikan Kota Pekanbaru Smart City Yang Madani, dan bagaimana upaya untuk bisa mewujudkan dan merealisasikannya dalam masa 5 Tahun yang akan datang. Penyampaian pandangan umum Fraksi dalam pembahasan Ranperda RPJMD Kota Pekanbaru 2017-2022 dilakukan pada tanggal 18 Oktober 2017. Kegiatan ini dihadiri oleh walikota Pekanbaru yang diwakili oleh asisten I SETDA Kota Pekanbaru, Anggota DPRD, FORKOPIMDA, pada pimpinan organisasi perangkat daerah (OPD), direktur BUMD, media massa dan beberapa undangan lainnya. 
Beberapa fraksi DPRD memberikan pandangan dan pertanyaan yang membutuhkan penjelasan lebih terkait dokumen draft RPJMD yang diserahkan sebelumnya. Sebagian besar pandangan umum fraksi melihat pentingnya pengkajian mendalam terkait visi, misi, dan agenda kepala daerah terpilih dalam tujuan, sasaran, strategi, dan kebijakan pembangunan yang merespon kebutuhan masyarakat dan aspirasi masyarakat. Selain itu diperlukan juga penjelasan terkait hasil evaluasi dari Provinsi serta singkronisasi dengan rencana strategis pembangunan diatasnya baik tingkat Provinsi hingga Nasional.

\section{Jawaban Pemerintah Terhadap Padangan Umum Fraksi DPRD Kota Pekanbaru dalam Rapat Paripurna tentang Ranperda RPJMD Kota Pekanbaru tahun 2017- 2022.}

Respon yang disampaikan oleh FraksiFraksi DPRD dalam pandangan umum tersebut, ditanggapi oleh Pemerintah Daerah Kota melalui jawaban Walikota Pekanbaru terhadap pandangan umum Fraksi-Fraksi DPRD Kota Pekanbaru. Interkasi antara Fraksi-Fraksi DPRD Kota Pekanbaru dengan Walikota Pekanbaru menjadi bahan untuk pembahasan dan persetujuan bersama Ranperda RPJMD Kota Pekanbaru menjadi Peraturan Daerah RPJMD Kota Pekanbaru yang akan dibahas lebih lanjut oleh Panitia Khusus, yang akan ditunjuk melalui Keputusan DPRD Kota Pekanbaru.

Tanggapan dan/atau jawaban pemerintah Kota Pekanbaru terhadap pandangan umum fraksi juga merupakan bentuk pelaksanaan dari komunikasi politik antara Walikota terpilih dengan DPRD yang juga tergabung didalam fraksi tertentu. Walikota terpilih menuangkan visi, misi, dan agenda pembangunan selama masa jabatannya kedalam dokumen RPJMD. Salah satu tujuan utama dari RPJMD adalah untuk menerjemahkan visi dan misi Walikota Pekanbaru dan Wakil Walikota Pekanbaru kedalam tujuan dan sasaran pembangunan daerah tahun 2012-2017, yang disertai dengan program prioritas untuk masingmasing OPD dan dalam penyusunannya memerlukan proses konsultasi dengan kekuatan politik yang ada di DPRD.

\section{Ekspose Kepala Bappeda Pekanbaru Mengenai RPJMD 2017-2022 dalam Rapat Kerja Panitia Khusus.}

Ekspose terhadap gambaran umum Ranperda RPJMD Kota Pekanbaru 2017-2022 merupakan bagian dari pembicaraan tingkat 1 yaitu rapat panitia khusus bersama pemerintah Kota Pekanbaru diantaranya Walikota Pekanbaru, Kepala BAPPEDA, Kepala BPKAD, Kepala Bagian ORTAL Setda Kota Pekanbaru, Kepala Bagian Hukum Setda Kota Pekanbaru beserta tenaga ahli. Kemudian kegiatan pembahasan disepakati dilanjutkan pada tanggal 1 November 2017 dengan agenda pembahasan Ranperda RPJMD Kota Pekanbaru 2017-2022.

Kepala BAPPEDA juga menyampaikan penekanan terhadap visi dan misi RPJMD dan kesesuaian terhadap RPJPD seperti penjelasan dibawah ini ${ }^{13}$

"Sesuai dengan amanat Peraturan Daerah Kota Pekanbaru Nomor 1 tahun 2011 tentang Rencana Pembangunan Jangka Panjang Daerah (RPJPD) Kota Pekanbaru Tahun 2005-2025, maka Visi Pembangunan Jangka Panjang Daerah Kota Pekanbaru 2005-2025 adalah:

“Terwujudnya Kota Pekanbaru sebagai Pusat Perdagangan dan Jasa, Pendidikan, serta Pusat Kebudayaan Melayu, Menuju Masyarakat Sejahtera yang Berlandaskan Iman dan Taqwa"

RPJMD Kota Pekanbaru 2017-2022 merupakan tahap ketiga dari pembangunan jangka daerah yang berlandaskan kepada pelaksanaan, pencapaian, dan sebagai kelanjutan RPJMD ke-2 dimana Visi RPJMD Kota Pekanbaru Tahun 2012-2017 adalah:

“Terwujudnya Kota Pekanbaru sebagai Kota Metropolitan yang Madani.” 
RPJMD ke-3 (2017-2022) ini ditujukan untuk memenuhi Tema pembangunan tahap lima tahun ke-3 (2016-2020) dari RPJPD Kota Pekanbaru 2005-2025, yaitu:

"Penataan Kota dan penyediaan infrastruktur yang memadai guna menunjang pengembangan Kota Pekanbaru sebagai pusat perdagangan dan jasa, pendidikan, dan pusat kebudayaan melayu, didukung dengan pemberdayaan usaha ekonomi rakyat, dan perbaikan kualitas sumber daya manusia”

Oleh karena itu, dengan mempertimbangkan tahapan pembangunan jangka panjang daerah, potensi, permasalahan dan tantangan pembangunan yang dihadapi serta isuisu strategis, maka dirumuskan Visi dan Misi Pembangunan Jangka Menengah Daerah Kota Pekanbaru tahun 2017-2022 sesuai dengan visi dan misi Walikota/Wakil Walikota terpilih sebagai berikut: “Terwujudnya Pekanbaru Sebagai Smart City Yang Madani”

Penjelasan dari terminologi Visi tersebut di atas dapat dijelaskan sebagai berikut:

Smart City, adalah: Terjemahannya adalah Kota Pintar atau Kota Cerdas, yaitu sebuah tatanan kota yang menggunakan sistem teknologi informasi sehingga memudahkan di dalam pengelolaan kota dan pelayanan warganya. Smart City ini meliputi 6 (enam) pilar, yaitu Smart Government (pemerintahan pintar), Smart Economy (ekonomi pintar), Smart Mobility (mobilitas pintar), Smart People (masyarakat pintar), Smart Living (lingkungan pintar), dan Smart Live (Hidup pintar).

Madani, adalah: Kota yang memiliki akhlak mulia, peradaban maju, modern, memiliki kesadaran sosial yang kuat, gotong royong, toleran, dalam sistem politik yang demokratis dan ditopang oleh supremasi hukum yang berkeadilan, berpendidikan maju, berbudaya Melayu, aman, nyaman, damai, sejahtera, bertanggungjawab serta berlandaskan iman dan taqwa”

Dalam rangka pencapaian visi yang telah ditetapkan dengan memperhatikan kondisi dan permasalahan yang ada, tantangan kedepan, serta memperhitungkan peluang yang dimiliki, maka ditetapkan 5 (lima) misi pembangunan jangka menengah daerah Kota Pekanbaru tahun 20172022, sebagai berikut:

1. Meningkatkan Sumber Daya Manusia(SDM) yang Bertaqwa, Mandiri, Tangguh dan Berdaya Saing Tinggi

2. Mewujudkan Pembangunan Masyarakat Madani Dalam Lingkup Masyarakat Berbudaya Melayu

3. Mewujudkan Tata Kelola Kota Cerdas dan Penyediaan Infrastruktur yang Baik

4. Mewujudkan Pembangunan Ekonomi Berbasiskan Ekonomi Kerakyatan dan Ekonomi Padat Modal, pada Tiga Sektor Unggulan yaitu Jasa, Perdagangan dan Industri (olahan dan MICE)

5. Mewujudkan Lingkungan Perkotaan yang Layak Huni (Liveable City) dan Ramah Lingkungan (Green City).

Pada tahapan ini interaksi DPRD dalam hal Pansus RPJMD dengan Pemerintah Kota lebih banyak membahas tentang visi dan misi Walikota. Periode kedua kepemimpinan Walikota Pekanbaru menawarkan konsep baru Smart City dengan menekan 6 Pilar yang disebutkan diatas dan program prioritas guna mencapai visi dan misi tersebut. Selain itu Pansus juga mengundang OPD terkait dalam pembahasan awal RPJMD ini guna melihat pemahaman dari OPD terkait visi, misi, tujuan dan sasaran Kepala Daerah selama masa jabatan dan menuangkan dan mengintegrasikannya kedalam program kerja OPD baik yang tertuang nantinya di Rencana Startegis OPD. Dari DPRD sendiri melalui Pansus memandang bahwa tidak terdapat dinamika yang kuat baik dari proses awal, keterlibatan fraksi hingga pembahasan ditingkat pansus. Hal yang paling utama dibahas lebih terkait penguatan visi misi Kepala Daerah.

DPRD memberi pandangan terkait urgensi mengundang Walikota untuk melakukan expose RPJMD dimana selain untuk memberikan catatan terhadap periode kepemimpinan Walikota 
sebelumnya dan juga dipandang perlu mengkaji dan mendalami visi dan misi Walikota Pekanbaru diperiode keduanya ini khususnya terkait istilah Smart City yang ditawarkan serta intergrasinya terhadap OPD dibawahnya.

\section{E. Ekspose Kepala Bappeda Pekanbaru Mengenai RPJMD 2017-2022 Setelah Diperbaiki Berdasarkan Konsultasi Rancangan Akhir RPJMD Kota Pekanbaru 2017-2022 ke Pemerintah Provinsi Riau dalam Rapat Kerja Panitia Khusus.}

Konsultasi rancangan akhir RPJMD dengan Pemerintah Provinsi lebih bertujuan untuk memperoleh saran pertimbangan berdasarkan landasan hukum penyusunan, sistematika dan teknis penyusunan, konsistensi menindaklanjuti kesepakatan hasil musrenbang RPJMD kabupaten/ kota, serta keselarasan dengan RPJPD kabupaten/ kota, RTRW kabupaten/kota, RTRW provinsi, RPJMN dan RPJMD dan RTRW provinsi dan RTRW kabupaten/kota lainnya seperti yang tertuang didalam Permendagri No. 54 Tahun 2010 Pasal 71.

Hasil konsultasi tersebut ditindaklanjuti oleh Pemerintah Daerah dan dibahas bersama Pansus pada tanggal 1 November 2017. Rapat Kerja Panitia Khusus ini bersama tim ahli dan pemerintah Kota Pekanbaru dengan agenda Ekspose Kepala Bappeda Pekanbaru mengenai RPJMD 2017-2022 setelah diperbaiki berdasarkan konsultasi rancangan akhir RPJMD Kota Pekanbaru 2017-2022 ke Pemerintah Provinsi Riau. Pada tahapan pembahasan Ranperda RPJMD ini terdapat beberapa masukan Ibu Ida Yulita Susanti, SH, MH selaku wakil ketua merangkap anggota panitia khusus Ranperda RPJMD Kota Pekanbaru 2017-2022 diantaranya berkaitan dengan ${ }^{14}$;

1. Pansus perlu melakukan extra percepatan penyelesaian pembahasan Ranperda RPJMD ini, hal ini berkaitan dengan batas waktu yang diberikan sampai pada 20 November 2017 Ranperda ini dapat diparipurnakan pengesahannya.

2. RPJMD ini sebagai tulang punggung kerja pemerintah Kota Pekanbaru agar sesuai dengan ketentuan dan tidak menimbulkan persoalan dikemudian hari.

3. RPJMD ini harus disusun untuk program kerja 5 tahun kedepan, agar terhindar dari program yang masuk ditengah jalan diluar dari program yang telah disusun di RPJMD ini.

4. RPJMD ini harus disempurnakan dan disesuaikan dahulu dengan catatan hasil konsultasi/evaluasi dari provinsi.

Selain itu juga pembahasan terkait 6 pilar smart city mendapat tanggapan dari beberapa anggota pansus diantaranya perlu pengkajian ulang 6 pilar smart city terkait kemampuan pemerintah daerah untuk merealisasikannya dan kesesuaian sasaran mengingat diperlukannya anggaran yang besar untuk mewujudkannya sedangkan kondisi keuangan daerah terus mengalami penurunan. Walaupun tidak bisa dipungkiri bahwa tujuan Smart City adalah kedepannya seluruh sektor akan berbasis IT dan tidak manual lagi sehingga akan mengurangi beban biaya seperti penggunaan kertas dan lebih optimal tenaga kerja.

\section{F. Finalisasi RPJMD Kota Pekanbaru 2017- 2022 dalam Rapat Kerja Panitia Khusus.}

Finalisasi RPJMD merupakan tahapan akhir dalam pembicaraan tingkat 1 dimana pansus bersama dengan pemerintah Kota Pekanbaru dan tenaga ahli membahas dokumen RPJMD yang telah melalui proses revisi dibeberapa tahapan baik evaluasi dair provinsi maupun pandangan dari anggota pansus DPRD. Selain itu Pansus juga menyusun laporan hasil kerja pansus yang nantinya disampaikan dalam rapat paripurna. Laporan hasil kerja pansus mengakomodir gambaran proses yang dilalui dalam membahas dokumen RPJMD ini dan pokok-pokok pikiran anggota pansus yang juga merupakan perwakilan dari anggota komisi dan fraksi. Pansus menyusun beberapa 
rekomendasi dan memandang diperlukannya pengurangan, penambahan dan penajaman baik secara konsepsional dalam bentuk narasi maupun secara substansi tentang hakikat dan arti penting RPJMD dalam penyelenggaraan fungsi pemerintahan daerah.

Dinamika dalam pembahasan peraturan daerah tentu tidak terhindarkan, hal ini sejalan dengan pelaksanaan fungsi legislasi yang melekat pada DPRD. Namun dalam pembahasan RPJMD Kota Pekanbaru tahun 2017-2022 ini tidak mengalami dinamika yang cukup alot dibandingkan pembahasan dokumen perencanaan pembangunan lainnya hal ini diantaranya diakibatkan tidak bertepatan dengan momentum politik serta kasibnya waktu pembahasan sehingga tidak menjadi komoditas politik di DPRD. Dalam pembahasan RPJMD Kota Pekanbaru juga tidak melalui proses pembahasan dengan Komisi atau Gabungan Komisi. Hal ini lebih disebabkan oleh singkatnya waktu pembahasan dan Anggota Pansus juga merupakan perwakilan dari komisi sehingga lebih mengefektifkan pembahasan ditingkat Pansus saja.

\section{G. Pengambilan Keputusan Bersama Terhadap Ranperda Kota Pekanbaru tentang RPJMD Kota Pekanbaru 2017- 2022 dalam Rapat Paripurna}

Pada pembicaraan tingkat II ini dilakukan dengan dua agenda utama yaitu penyampaian Laporan Panitia Khusus DPRD Kota Pekanbaru dalam Rapat Paripurna Terhadap Ranperda Kota Pekanbaru tentang RPJMD Kota Pekanbaru 2017-2022 dan dilanjutkan dengan Pendapat Akhir Kepala Daerah Terhadap Laporan Panitia Khusus DPRD Kota Pekanbaru tentang Ranperda RPJMD Kota Pekanbaru tahun 2017-2022. Kegiatan ini dilakukan pada tanggal 20 November 2017.

\section{1) Laporan Panitia Khusus DPRD Kota Pekanbaru dalam Rapat Paripurna}

Tahapan selanjutnya yaitu penyampaian laporan panitia khusus DPRD Kota Pekanbaru dalam Rapat Paripurna terhadap Ranperda Kota Pekanbaru tentang RPJMD Kota Pekanbaru 2017-2022 dan ditutup dengan pengambilan keputusan dan persetujuan dewan terhadap laporan hasil kerja Pansus.

Pembahasan yang dilakukan oleh Pansus Tentang Rencana Pembangunan Jangka Menengah Daerah (RPJMD) Kota Pekanbaru Tahun 20172022 setelah Pemerintah Kota Pekanbaru melakukan konsultasi Draf RPJMD Pekanbaru 2017-2022 ke Pemerintah Daerah Provinsi Riau, Maka Pansus perlu melakukan pengurangan, penambahan dan penajaman baik secara konsepsional, dalam bentuk narasi maupun secara substansi mengenai hakikat dan arti penting RPJMD Kota Pekanbaru Tahun 2017-2022 dalam penyelenggaraan Fungsi Pemerintahan Daerah di Kota Pekanbaru. Setelah panitia khusus membahas, menganalisa dan memberikan pemikiran dalam pembahasan RPJMD 20172022 Kota Pekanbaru, maka sebelum dimintakan persetujuan kepada anggota DPRD Kota Pekanbaru dalam sidang paripurna, pansus juga memberikan beberapa rekomendasi kepada pemerintah Kota Pekanbaru.

Terkait proses yang dilalui pada pembicaraan tingkat II ini juga diwarnai dengan interupsi namun tidak mempengaruhi tahapan selanjutnya yaitu pendapat akhir kepala daerah terhadap Laporan Panitia Khusus DPRD Kota Pekanbaru tentang Ranperda RPJMD Kota Pekanbaru tahun 2017-2022 serta pengambilan persetujuan bersama terkait draft keputusan bersama tersebut. Pandangan akhir fraksi tidak dilakukan mengingat pokok-pokok pikiran fraksi telah tertuang didalam pembahasan ditingkat Pansus. Selain itu terkait tidak adanya tahapan penyampaian pandangan akhir fraksi karena seluruh catatan fraksi telah dibahas dan diakomodir dipembicaraan tingkat I di Pansus dan kasipnya waktu pembahasan RPJMD. 
1) PendapatAkhir Kepala Daerah Terhadap Laporan Panitia Khusus DPRD Kota Pekanbaru tentang Ranperda RPJMD Kota Pekanbaru tahun 2017-2022 dan Persetujuan Bersama Kepala Daaerah dengan DPRD

Setelah laporan hasil kerja Pansus DPRD tentang RPJMD Kota Pekanbaru 2017-2022 disetujui anggota dewan, tahapan selanjutnya yaitu penyampaian pendapat akhir kepala daerah terhadap Laporan Panitia Khusus DPRD Kota Pekanbaru tentang Ranperda RPJMD Kota Pekanbaru tahun 2017-2022. Pendapat akhir ini berisikan apresiasi kepada semua pihak yang terlibat dalam proses membahas, menganalisis, mengkaji lebih dalam serta memberikan sumbangsih saran dan masukan terhadap Ranperda RPJMD Kota Pekanbaru Tahun 2017-2022. Selain itu dilakukan juga penekanan pada tahapan selanjutnya yaitu penetapan yang didahului dengan evaluasi Ranperda oleh Gubernur Provinsi Riau.

Selanjutnya dilakukan pembacaan draft keputusan bersama DPRD Kota Pekanbaru dan Walikota Pekanbaru tentang Persetujuan Bersama terhadap Ranperda tentang RPJMD Kota Pekanbaru Tahun 2017-2022 dan kemudian dilakukan pengambilan persetujuan bersama terkait draft keputusan bersama tersebut. Tahapan akhir dilakukan penandatanganan keputusan bersama DPRD Kota Pekanbaru dan Walikota Pekanbaru tentang Ranperda tentang RPJMD Kota Pekanbaru Tahun 2017-2022

\section{KESIMPULAN}

Berdasarkan hasil penelitian diatas maka dapat ditarik kesimpulan bahwa; Proses Politik Perumusan Rancangan Peraturan Daerah RPJMD Kota Pekanbaru 2017-2022 menjadi Peraturan Daerah RPJMD Kota Pekanbaru 2017-2022 pada Dewan Perwakilan Rakyat Daerah Kota Pekanbaru dimulai dalam Rapat Paripurna Dewan Perwakilan Rakyat Daerah Kota Pekanbaru yaitu pandangan umum Fraksi yang ada di DPRD Kota Pekanbaru terhadap Rancangan Peraturan Daerah
RPJMD Kota Pekanbaru 2017-2022, setelah itu tanggapan pemerintah kota Pekanbaru terhadap pandangan umum Fraksi-Fraksi di DPRD Kota Pekanbaru. Pada tahap berikutnya pembahasan dilakukan dalam arena Panitia Khusus (Pansus) DPRD RPJMD Kota Pekanbaru bersama Tim RPJMD Kota Pekanbaru yang membahas BabBab yang ada di dalam RPJMD Kota Pekanbaru, dan setelah pembahasan di Pansus selesai, maka hasil pembahasan Pansus dilaporkan dalam Rapat Paripurna Dewan Perwakilan Rakyat Daerah Kota Pekanbaru serta pendapat akhir kepala daerah terhadap laporan panitia khusus DPRD Kota Pekanbaru tentang Ranperda RPJMD Kota Pekanbaru tahun 2017-2022 dan persetujuan bersama kepala daaerah dengan DPRD terhadap Ranperda tentang RPJMD Kota Pekanbaru Tahun 2017-2022.

Hasil dari Proses Politik Perumusan Rancangan Peraturan Daerah RPJMD Kota Pekanbaru 2017-2022 menjadi Peraturan Daerah RPJMD Kota Pekanbaru 2017-2022 mengakibatkan terjadi perubahan beberapa materi baik yang terdapat pada Bab-Bab RPJMD, narasi, dan redaksional, maupun bagian yang ada dalam dokumen awal rancangan Perda RPJMD Kota Pekanbaru menjadi hasil akhir dokumen RPJMD Kota Pekanbaru.

\section{DAFTAR PUSTAKA}

Abdul Wahap, Solichin, 2008, Analisis Kebijakan dari Formulasi ke Implementasi Kebijaksanaan Negara, Jakarta; PT Bumi Aksara.

Agustino, Leo. 2008. Dasar-dasar Kebijakan Publik. Bandung: Alfabeta

Arsyad, Lincolin 1999, Pengantar Perencanaan dan Pembangunan Ekonomi Daerah, Yogyakarta; Badan Penerbit Fakultas Ekonomi UGM.

Deddy, Supriady B, Riyadi. 2005. Perencanaan Pembangunan Daerah Strategi Menggali Potensi dalam Mewujudkan Otonomi 
Daerah. Jakarta; PT Gramedia Pustaka Utama.

Sjafrizal, 2014. Perencanaan Pembangunan Daerah di Era Otonomi. Jakarta; PT. Raja Grafindo Persada.

M. L. Jhingan. 2013. Ekonomi Pembangunan dan Perencanaan. Jakarta: PT RajaGrafindo Persada.

Nugroho D, Riant, 2003. Kebijakan Publik Formulasi, Implementasi dan Formulasi. Jakarta: PT Elex Media Komputindo.

Winarno, Budi, 2007, Kebijakan Publik, Teori, dan Proses, Jakarta; Media Presindo.

\section{Footnote:}

1 Agustino Leo. 2008. Dasar-dasar Kebijakan Publik. Bandung: Alfabeta, Hlm 7

2 Solichin Abdul Wahap, 2008, Analisis Kebijakan dari Formulasi ke Implementasi Kebijaksanaan Negara, Jakarta; PT Bumi Aksara. Hlm 40-50

3 Budi Winarno, 2007, Kebijakan Publik, Teori, dan Proses, Jakarta; Media Presindo, Hlm 17

4 Budi Winarno, Op, Cid. Hlm 32-34

5 Sjafrizal. Op.Cid, Hlm. 24

$6 \quad$ M. L. Jhingan. 2013. Ekonomi Pembangunan dan Perencanaan. Jakarta: PT RajaGrafindo Persada. Hlm 57
Sjafrizal, Op.Cid, Hlm 25.

8 Lincolin Arsyad, Op.Cid, Hlm 78-80

9 Riyadi dan Deddy Supriady B. 2005. Perencanaan Pembangunan Daerah Strategi Menggali Potensi dalam Mewujudkan Otonomi Daerah. Jakarta; PT Gramedia Pustaka Utama. Hlm 10-15.

10 Ibid., Hlm 22-24

11 Miles, B. Mathew dan Michael Huberman. 1992. Analisis Data Kualitatif Buku Sumber Tentang Metode-metode Baru. Jakarta: UIP. HIm 15-16

12 Risalah rapat paripurna dengan agenda Penyampaian oleh Walikota Pekanbaru tentang Ranperda RPJMD Kota Pekanbaru tahun 2017-2022 tanggal 09 Oktober 2017.

13 Disadur dari dokumen RPJMD Kota Pekanbaru dan Materi Expose draft RPJMD Kota Pekanbaru Tahun 2017-2022 oleh Kepala BAPPEDA Kota Pekanbaru.

14 Notulensi Rapat Pansus Rapat Kerja Panitia Khusus ini bersama tim ahli dan pemerintah Kota Pekanbaru dengan agenda Ekspose Kepala Bappeda Pekanbaru mengenai RPJMD 2017-2022 setelah diperbaiki berdasarkan konsultasi rancangan akhir RPJMD Kota Pekanbaru 2017-2022 ke Pemerintah Provinsi Riau. 1 November 2017. 